\title{
Supply-Demand Gap Analysis and Projection for Major Pulses in India
}

\author{
Vilas Jadhav ${ }^{1 *}$, Mallikarjuna Swamy, N² and Gracy, C.P. ${ }^{3}$ \\ ${ }^{1}$ Department of Agricultural Development and Rural Transformation Centre, Institute for Social and Economic Change, \\ Bengaluru-560072, Karnataka, India \\ ${ }^{2}$ Department of Agricultural Economics, UAS, GKVK, Bengaluru-560065, Karnataka, India \\ ${ }^{3}$ Department of Agricultural Marketing, Cooperation \& Business Management, University of Agricultural Sciences, GKVK, \\ Bengaluru-560065, Karnataka, India
}

"Corresponding author: vilasagri@gmail.com

\begin{abstract}
India is the global leader in terms of production, consumption and import of pulses. The pulses production has been stagnating over the years leading to widening gap between demand and supply. About 20 percent of the total pulses demand is met through imports. The present study is an attempt to analyze the production growth, supply-demand gap and projection of availability of major pulses viz., gram (Chickpea) and tur (Pigeon pea), in India. The highest growth rates in total pulses production was recorded between 1966-67 to 1975-76 period and from 2006-07 to 2015-16 exhibiting 2.05 per cent and 2.62 per cent increase. Gram (Chickpea) recorded the highest production growth between the period from1989-87 to 1995-96 and 2006-07 to 2015-16 and respective figure were 2.78 percent and 2.79 percent. Whereas, tur (Pigeonpea) showed accelerated growth rate of 2.72 per cent in area, 4.30 per cent growth in production during 1976-77 to 1985-86 period. The study found that there is a big gap in supply and demand of major pulses in India, suggesting a shortage of pulse for domestic consumption to the tune of 114.50 lakh tonnes of Gram (Chickpea) and 365.60 lakh tonnes of Tur (Pigeon pea) during 2030.
\end{abstract}

Keywords: Supply-demand gap of pulses, projection of supply-demand and population

Pulses are an important group of field crops that provide good quality protein complementing cereal proteins for principally vegetarian population of the country (Directorate of Pulses Development, 2016). Pulses are popularly known as "Poor man's meat" and "rich man's vegetable", contribute significantly to the nutritional security of the country. India is the world leader in production, consumption and import as well. In India pulses are cultivated in both kharif (autumn harvested crop) and rabi (Spring harvested crop) season, though rabi season accounts for higher share of total pulses produced in the country. The important pulses produced in India are, gram (Chickpea), tur (Pigeon pea), urad (Black gram), moong (Green gram), masoor (lentils) and peas (Commodity profile for pulses, 2017).
Production of pulses has increased significantly from 14.7 million tonnes in 2009-10 to 17.82 million tonnes in 2016-17. Export of pulses except kabuli chana has been banned since 2006. Whereas, import of total pulses has increased from 2.82 million tonnes in 2008 to 4.67 million tonnes in 2016-17. Total availability of pulses for domestic consumption (production + imports- exports) in 2016-17 was 22.22 million tonnes which is close to availability of pulses in the previous year (DES 2017).

Pulses play a predominant role in food and nutritional security due to their high nutritional value (20-30\% protein) (Srivastava et al., 2010). Pulse culivation also enhance the productivity of soil, thereby enhancing the yield of subsequent crops, hence they are referred to as environment 
sustaining crops. Increase in yield of subsequent crops to the tune of about 20-40 per cent has been recorded (Pande and Joshi, 1995; IIPR, 1998; 1999). In India, pulses are grown throughout the year due to favorable agro-climatic conditions. The growth in production and productivity of pulses has lagged behind the population growth rate which has resulted in decline in per capita availability of pulses from $60 \mathrm{~g} /$ day/capita in 1951 to $31 \mathrm{~g} /$ day/capita in 2009 (ICMR recommends $65 \mathrm{~g} /$ day/capita) due to stagnant/ decreasing production and rapid increase in population.

The poor production performance of pulses has created an imbalance in demand and supply of pulses, soaring import bills, unpredictable price rises and low net profit compared to their competing crops (Joshi and Saxena, 2002). This coupled with economic factors like lack of assured market, ineffective government procurement, unfavorable parity in prices and trade liberalization make pulses cultivation unremunerative and less attractive compared to other crops (Byerlee and White, 1997; Joshi et al. 2000; Chand, 2000). Further, only a few states endow major share of pulses production in India and there exists a wide variability in their yield across different states. Keeping this in view, the present paper has made an attempt to study the supply-demand gap analysis and growth performance of major pulses and projection of supply and demand up to 2030.

\section{MATERIALS AND METHODS}

The present study is based on secondary data obtained from various Government publications and reports. The growth of major pulses crops to total pulses was analyzed for six different periods, viz. (Period-1, 1956-57 to 1965-66), (Period-2, 1966-67 to 1975-76), (Period-3, 1976-77 to 1985-86), (Period-4, 1989-87 to 1995-96), (Period-5, 1996-97 to 2005-06) and (Period-6, 2006-07 to 2015-16). The equation of exponential curve was used to measure the growth in area, production and yield of major pulses. The time series data for the different periods on area, production and productivity of total pulses, gram and tur crops were collected from Directorate of Economics and Statistics (DES), Government of India (GOI), Ministry of Agriculture and Farmers welfare, Department of Agriculture Cooperation and Farmers Welfare, New Delhi.
The present study is based on secondary data collected from Household consumer expenditure for India, 2012-13, NSS $70^{\text {th }}$ round (January December, 2013) and the variables considered were monthly per capita consumer expenditure, quantity and value of consumption. Because of the non availability of data on income, the total expenditure was used as a proxy for income and has been used as an independent variable. The data on population for India was collected from census of India for the year 2001 and 2011 to project the population for 12th and 13th five-year plan period. The information on Gross Domestic Product (GDP) at Factor Cost by Industry of origin in India A At 2004-05 Constant Prices for 2004-05 to 2012-13\} was collected from Directorate of Economics and Statistics, India and this is used for the computation of income growth.

\section{ANALYTICAL TECHNIQUES}

\section{Growth in Area under Major Pulses}

Growth rates for area, production and productivity were computed for a period of 65 years from 1950-51 to 2015-16 for two major pulse crops. Exponential growth model was selected for the analysis and the compound growth rates (CGR) of the selected parameters were calculated by fitting the following equation.

$$
Y=A B^{t}
$$

Where, $Y=$ area, production or yield of the crop, $\mathrm{A}=$ constant $\mathrm{t}=$ time period and $\mathrm{B}=$ coefficient $\mathrm{to}$ be estimated. Then, the CGR (\%) was obtained as follows:

$$
r=(\operatorname{Exp}(\mathrm{B})-1) \times 100
$$

The significance of ' $r$ ' was tested by working out $\mathrm{t}$-value ' $\mathrm{t}$ ' $=\mathrm{r} \mathrm{SE}(\mathrm{r})$.

Where, ' $t$ ' follows student's $t$ - distribution with (n-2) degrees of freedom.

\section{Per Capita Income Growth}

To find the income growth for India, GDP of the country was regressed on time by using the functional form:

$$
\text { Ln (GDP of country) }=\alpha+\beta(t)+\varepsilon
$$

Similarly, the income growth for India is computed 
by fitting regression of GDP from agriculture on time and is as follows:

$$
\text { Ln (GDP from agriculture })=\alpha+\beta(t)+\varepsilon
$$

Where $\mathrm{t}=$ time and $\varepsilon=$ random disturbance term.

The growth of GDP from agriculture is taken as proxy for income growth of India.

The above equations were estimated using the Ordinary Least Square (OLS) technique. The Compound growth rate (CGR) in percentage is computed from the relationship:

$$
\mathrm{CGR}=[\operatorname{Exp}(\beta)-1]^{*} 100
$$

The significance of the regression coefficient was tested using the student's ' $t$ ' test.

\section{Estimation of Demand Elasticities using Appropriate Functional Form}

Demand elasticities are important parameters for projecting future demand. However, the magnitude of demand elasticity of a commodity largely depends on the model chosen by the analyst. Log -inverse, transcendental, double-log, Log-log -inverse, linear, quadratic and semi- log are among the models used for computing expenditure elasticities for tur (Pigeon pea), and gram (Chickpea).

\section{Income Elasticity of Demand}

Income elasticity of demand is the degree of responsiveness of demand to a change in income. In technical terms it is the ratio of the percentage change in demand to the percentage change in income. Thus,

$\mathrm{Ep}=$ Percentage change in quantity demanded/ Percentage change in income

Mathematically, $\mathrm{E}_{\mathrm{p}}=\left[\frac{\Delta q}{\Delta p}\right] *\left[\frac{p}{q}\right]$

Where,

$\mathrm{Y}=$ Monthly per capita expenditure on a specific pulses item in rupees

$X=$ Monthly per capita total consumption expenditure in rupees

$\mathrm{a}, \mathrm{b}$ and $\mathrm{c}$ are the regression coefficients.

$\mathrm{u}=$ Random error term
The monthly per capita total consumption expenditure has been used as proxy for income. Since, the data on consumer income was not available in NSSO publications.

The expenditure elasticities ( $e_{x}$ ) for each commodity are derived from the derivatives of each equation with respect to expenditure as follows:

$$
\mathrm{e}_{\mathrm{X}}=[\mathrm{dY} / \mathrm{dX}]^{*}[\mathrm{X} / \mathrm{Y}]
$$

The elasticities $\left(e_{X}\right)$ evaluated at the sample mean values for $X$ and $Y$ for different functions respectively. All the functions are fitted to the data and better fit was decided based on the value of the coefficient of determination $\left(\mathrm{R}^{2}\right)$ and standard errors of the coefficients.

\section{RESULTS AND DISCUSSION}

\section{Share of Major Pulses to Total Pulses Production in India}

The study is confined to two major pulses, namely gram (Chickpea) share was 41 per cent followed by tur (Pigeon pea), 19 per cent of total share, thus contributing to more than 60 per cent of total pulse production in 2017 (Table 1). During 20115-16 share of gram (Chickpea) to total pulses production was 43.18 per cent, while that of tur (Pigeon pea) was 15.65 per cent followed by urad bean 11.92 per cent, moong 9.72 per cent and others 19.52 per cent (lentil, field peas, horse gram and sweet pea). Whereas, during 2016-17 the production of gram to total pulses was 41.20 per cent followed by tur (19.10\%), urad bean (13.05\%), moong (9.62 \%) and others $(17.03 \%)$.

\section{Growth Performance of Pulses in India}

During the past six decades, area under pulses increased marginally compared to 22 per cent increase for cereals. More importantly, increment in pulse production has been only 32 per cent as compared to about 280 per cent in the case of cereals during this period. Yield also has shown a similar trend with only 25 per cent increase in pulses as compared to 211 per cent in cereals. It reflects the stagnation of pulses production and a virtual negligence of planning in pulses development and a structural shift in production performance of pulses-producing states not only validates the lack 
Table 1: Share of Major Pulses Production to Total Pulses in India

[Thousand Tonnes]

\begin{tabular}{ccccc}
\hline Pulse Crops & $\mathbf{2 0 1 5 - 1 6}$ & Share in Total Production (\%) & $\mathbf{2 0 1 6 - 1 7}$ & Share in Total Production (\%) \\
\hline Gram (Chickpea) & 7060.00 & 43.18 & 9120.00 & 41.20 \\
Tur (Pigeon pea) & 2560.00 & 15.65 & 4230.00 & 19.10 \\
Urad & 1950.00 & 11.92 & 2890.00 & 13.05 \\
Moong & 1590.00 & 9.72 & 2130.00 & 9.62 \\
Other Pulses & 3190.00 & 19.52 & 3770.00 & 17.03 \\
Total Pulses & 16350.00 & 100.00 & 22140.00 & 100.00 \\
\hline
\end{tabular}

Source: Directorate of Economics and Statistics (DES)*: Based on $2^{\text {nd }}$ Advance Estimates for 2016-17.

Table 2: Compound Annual Growth Rates (CAGR) of Pulses

(1956-57 to 2015-16) [\%]

\begin{tabular}{lccccccccc}
\hline \multirow{2}{*}{ Periods } & \multicolumn{3}{c}{ Gram (Chickpea) } & \multicolumn{3}{c}{ Tur (Pigeon pea) } & \multicolumn{3}{c}{ Total pulses } \\
\cline { 2 - 9 } & Area & Prodn & Yield & Area & Prodn & Yield & Area & Prodn & Yield \\
\hline 1956-57 to 1965-66 & -1.55 & $-2.89^{*}$ & -1.35 & $1.04^{* * *}$ & -0.72 & -1.75 & 0.06 & -0.61 & -0.66 \\
1966-67 to 1975-76 & -0.38 & 0.43 & 0.81 & -0.02 & 2.84 & 2.87 & 0.26 & 1.17 & 0.94 \\
1976-77 to 1985-86 & -0.74 & 0.07 & 0.67 & $2.72^{* * *}$ & $4.30^{* *}$ & 1.67 & 0.62 & 2.05 & 1.43 \\
1989-87 to 1995-96 & 1.00 & 2.78 & $1.79^{*}$ & 0.55 & -1.17 & -1.05 & -0.19 & 1.06 & 1.25 \\
1996-97 to 2005-06 & -0.94 & -1.11 & -0.18 & 0.28 & 0.38 & 0.10 & 0.05 & 1.00 & -0.48 \\
2006-07 to 2015-16 & $1.71^{* *}$ & $2.79^{*}$ & $1.08^{*}$ & $1.18^{*}$ & 1.51 & 0.18 & 0.92 & $2.62^{* * *}$ & $1.88^{*}$ \\
\hline
\end{tabular}

Note: Indicates ${ }^{* *}, * *$, and $*, 1,5$ and 10 per cent level of significance respectively.

of spatial and temporal stability in their production performance but also throws light on the hidden potential of minor states in pulses production for long-term sustainability of pulse production (Mittal, 2006, Srivastava et al. 2010).

The results on growth rates in area, production and productivity of pulse crops are presented in table 2. From 1956-57 to 2015-16, the total acreage under pulses has almost been stagnated, however, a little growth rate in area was recorded between the period from 1966-67 to 1975-76 (0.06\%) and during 2006-07 to 2015-16 was 0.92 per cent. The maximum total pulses production growth rates were 2.05 per cent and 2.62 per cent and maximum growth rate of total pulse yield of 1.43 percent and 1.88 per cent were also observed during the same period and they were significant at five per cent and one per cent levels, respectively.

However, the annual compound growth rate of chickpea was significant and highly impressive for area, production and productivity during study periods. The annual compound growth rate in area was the highest at one percent between the periods from 1989-87 to 1995-96 and it was 1.71 per cent during 2006-07 to 2015-16. Whereas, highest production growth rates of chickpea were 2.78 per cent and 2.79 per cent and yield growth rate of gram was the highest at 1.79 percent and 1.08 per cent were also observed during the same period and were statistically significant at five per cent and one per cent levels. In the case of tur, accelerated growth rate in area $(2.72 \%)$, production $(4.30 \%)$ and productivity (1.67\%) during 1976-77 to 198586 , followed by 1.18 per cent in the case of area, 1.51 per cent in the case of production and meagre 0.18 percent during the 2006-07 to 2015-16 period. The lower productivity of pulse crops are due to lack of sufficient irrigation, below normal rainfall and undertaking pulse crops under rain-fed conditions.

\section{Projected Supply for Major Pulses in India}

Recently, India signed an agreement with Mozambique for import of pulses for next five years. There is significant demand for pulses in India. Consumption of pulses in India is over 22 million tonnes, where as India produces less than 19 million tonnes of pulses annually. This necessitates import of pulses from 46 countries. 
Similar studies conducted by using Artificial Neural Networks (ANN) method, which has been successfully employed in many fields in recent years provides realistic results regarding predictions, is applied in order to perform a future oriented projection of Non-Wood Forest Products (Yildirim et al. 2014; Farjam et al. 2014 and Safa et al. 2015).

The successful agricultural development and production plans in India have been to generate the rate of growth in pulse production to meet the growing demand for pulse consumption with respect to growing population and per capita income. An attempt has been made to forecast the area and production of major pulse crops to examine the supply position. The linear regression model of area and production on time (independent variable) is fitted to get the coefficients of the model for each of the major pulse crops and growth rates (g) of area and production for different pulse crops were computed. The growth rates for area and production obtained accordingly for different crops under the investigation was used to forecast area and production for the respective crops. The results of the forecast area and production up to 2030 for both the crops viz., gram and tur are presented in Table 3.

Table 3: Projected Supply for Major Pulses in India (Area in Lakh ha, Production in Lakh tonnes)

\begin{tabular}{cccccc}
\hline \multirow{2}{*}{$\begin{array}{c}\text { Sl. } \\
\text { No. }\end{array}$} & \multirow{2}{*}{ Year } & \multicolumn{2}{c}{ Gram (Chickpea) } & \multicolumn{2}{c}{ Tur (Pigeon pea) } \\
\cline { 3 - 6 } & & Area & Production & Area & Production \\
\hline 1 & 2016 & 65.40 & 56.50 & 37.10 & 26.00 \\
2 & 2017 & 65.11 & 56.70 & 37.20 & 26.10 \\
3 & 2018 & 64.83 & 56.91 & 37.50 & 26.30 \\
4 & 2019 & 64.41 & 57.12 & 37.71 & 26.50 \\
5 & 2020 & 64.10 & 57.30 & 38.00 & 26.70 \\
6 & 2021 & 63.80 & 57.51 & 38.30 & 26.90 \\
7 & 2022 & 63.51 & 57.71 & 38.50 & 27.00 \\
8 & 2023 & 63.20 & 57.90 & 38.80 & 27.20 \\
9 & 2024 & 62.80 & 58.01 & 39.00 & 27.40 \\
10 & 2025 & 66.62 & 55.70 & 36.00 & 25.30 \\
11 & 2026 & 66.30 & 55.90 & 36.20 & 25.50 \\
12 & 2027 & 66.00 & 56.11 & 36.50 & 25.60 \\
13 & 2028 & 65.70 & 56.22 & 36.70 & 25.70 \\
14 & 2029 & 65.31 & 56.42 & 37.00 & 25.90 \\
15 & 2030 & 65.00 & 56.63 & 37.21 & 26.10 \\
\hline
\end{tabular}

Supply forecast is made based on 60 previous years data starting from 1956-57 to 1965-66 to 2006-07 to 2015-16. Gram area was 83.99 lakh hectares with a production of 70.58 lakh tonnes during 2015-16. However, the forecasted area of gram would be 65 lakh hectares with a production of 56.63 lakh tonnes during 2030 which indicate meager increase in area and production of gram. In the case of tur, as against an area of 39.63 lakh hectare with a production of 25.61 lakh tonnes during 2015-16, the area and production forecast of tur for the year 2030 would be 37.21 lakh hectares and corresponding production is likely to be 26.10 lakh tonnes.

\section{Per Capita Income Growth}

The per capita income growth is estimated using time series data over 2004-05 to 2011-12. Log linear regression was fitted by regressing GDP on time to estimate growth in per capita income. The results are presented in Table 4 . The growth in per capita income in India was 9.01 per cent which is statistically significant at five per cent level.

Table 4: OLS Estimates of per capita Income

\begin{tabular}{cccc}
\hline Variable & Intercept $(\boldsymbol{\alpha})$ & Slope $(\beta)$ & $\mathbf{R}^{2}$ \\
\hline Income growth & $\begin{array}{c}14.74^{*} \\
(0.0049)\end{array}$ & $\begin{array}{c}0.09^{*} \\
(0.0021)\end{array}$ & 0.90 \\
\hline
\end{tabular}

Note: Data in the parenthesis indicates standard error; ${ }^{*}$ Indicates significance at 5 per cent level.

\section{Expenditure Elasticities of Demand for Major pulses}

Numerous studies have employed Engel curves for projection of demand based on the NSS data. In the present study different forms of Engel curves namely, linear, semi-log, double-log, inverse and quadratic curves were fitted to major pulses crops. The best functional fit was chosen on the basis of high $\mathrm{R}^{2}$. It may be noted here that usually it is desired that the functional form satisfies certain economic criteria, but none of the functional form used in the literature satisfy all the economic criteria simultaneously. In the present study chosen functional forms represents the data set in a fairly good manner. In other words, the functions which have been chosen explain the maximum variation in the dependent variable. The advantage of Engel curve is that it takes into account income (expenditure as proxy), an important determinant of consumption pattern. 
The $70^{\text {th }}$ round of household consumer expenditure survey carried out by NSSO during the year 201314 data published by NSSO was used to carryout demand projection exercise. The time series data facilitate to capture variations in consumption pattern while estimating expenditure elasticities.

Table 5: Expenditure Elasticity for Major Pulses

\begin{tabular}{ccccccc}
\hline $\begin{array}{c}\text { S1. } \\
\text { No. }\end{array}$ & Item & $\begin{array}{c}\text { Functional } \\
\text { Form }\end{array}$ & a & B & $\mathbf{R}^{2}$ & Elasticities \\
\hline \multirow{2}{*}{1} & Gram & Semi-log & $\begin{array}{r}-23.97 \\
(9.52)\end{array}$ & $\begin{array}{c}4.44^{*} \\
(1.33)\end{array}$ & 0.69 & 0.55 \\
& & & $\begin{array}{r}-54.97^{*} \\
10.19^{*}\end{array}$ & & \\
2 & \multirow{2}{*}{ Tur } & Semi-log & & \\
& & & $(24.62)$ & $(3.42)$ & 0.63 & 0.54 \\
\hline
\end{tabular}

Source: Based on NSSO data on consumption for 2013-14; Note: Figures in the parenthesis represent the standard error of the estimates. *Significant at 5 per cent level.

The results on parameters estimated of different functional forms utilized for computation of expenditure elasticities for major pulse crops are presented in Table 5. The demand parameters are estimated to examine the effect of changes in the income. The dependant variable is the expenditure share of each food item. The independent variable of the equation includes the total household expenditure. It may be observed from table 5 that semi log emerged as better functional form for gram and tur.

The estimated results showed that the coefficients of the explanatory variable were significant for gram and tur. In the case of tur both intercept and co-efficient were significant at five per cent level of significance. The demand function for gram could capture only five per cent of the variation with none of the coefficient being significant. We may note here that other functional forms also did not provide better fit for both crops.

\section{Projected Population and demand}

Population projection is one of the prerequisite to undertake demand projection exercise. The population data for all India published by the census of India for the years 2001 and 2011 is utilized to project the total population of the country by 2030 in the Table 6. It may be noted from the table that populations would be 1265.20 million during 201516 , and the projected population would be 1613.30 million during 2030. Whereas, demand forecast for gram and tur would be 171.10 lakh tonnes and 391.70 lakh tonnes during 2030.

Table 6: Projected Population and Demand for Major Pulses

(demand in lakh tones)

\begin{tabular}{ccccc}
\hline $\begin{array}{c}\text { Sl. } \\
\text { No. }\end{array}$ & Year & $\begin{array}{c}\text { Population } \\
\text { (in millions) }\end{array}$ & Gram & Tur \\
\hline 1. & 2016 & 1285.87 & 41.62 & 95.80 \\
2. & 2017 & 1306.87 & 46.00 & 105.91 \\
3. & 2018 & 1328.22 & 50.92 & 117.10 \\
4. & 2019 & 1349.92 & 56.30 & 129.61 \\
5. & 2020 & 1371.97 & 62.31 & 143.30 \\
6. & 2021 & 1394.38 & 68.92 & 158.50 \\
7. & 2022 & 1417.16 & 76.20 & 175.21 \\
8. & 2023 & 1440.31 & 84.31 & 193.72 \\
9. & 2024 & 1463.84 & 9.33 & 214.20 \\
10. & 2025 & 1487.75 & 103.20 & 236.91 \\
11. & 2026 & 1512.05 & 114.11 & 261.90 \\
12. & 2027 & 1536.75 & 126.30 & 289.72 \\
13. & 2028 & 1561.86 & 139.81 & 320.33 \\
14. & 2029 & 1587.36 & 154.62 & 354.31 \\
15. & 2030 & 1613.30 & 171.10 & 391.70 \\
\hline
\end{tabular}

The exercise on population projection can be done either on the basis of 'compound growth rate' or by the 'component method'. Since details on fertility, mortality and migration are not available, the first method is adopted. Population projections are made using the formula described in the methodology.

Estimates of food grains consumed by households were obtained from the NSSO, which prepares these estimates based on nationwide surveys. Estimates are provided both for the country and as well as for states (However, no accurate estimates are available about the quantity of food grains going into feed, seed, industrial use and wastage. Similarly, food grains consumed as food outside homes and in various types of bakery products, except bread, are not included in the NSSO estimates).

Population trends project India to emerge as the most populous country in the world in the coming decades. Therefore, demand and supply of food commodities has become important for country's food security concerns in the future. Because, the imbalance between production and demand impacts the prices and profitability, which intern adversely affects the poor people and farming community. 
Table 7: Supply and Demand Gap Analysis for Major pulses

(Demand in lakh tonne)

\begin{tabular}{cccccccc}
\hline \multirow{2}{*}{ S1. No. } & \multirow{2}{*}{ Year } & \multicolumn{3}{c}{ Gram (Chickpea) } & \multicolumn{3}{c}{ Tur (Pigeon pea) } \\
\cline { 3 - 7 } & & Supply & Demand & Gap & Supply & Demand & Gap \\
\hline 1. & 2015 & 56.3 & 37.5 & 18.8 & 25.8 & 86.6 & -60.8 \\
2. & 2016 & 56.5 & 41.6 & 14.9 & 26.0 & 95.8 & -69.8 \\
3. & 2017 & 56.7 & 46.0 & 10.7 & 26.1 & 105.9 & -79.8 \\
4. & 2018 & 56.9 & 50.9 & 6.0 & 26.3 & 117.1 & -90.8 \\
5. & 2019 & 57.1 & 56.3 & 0.8 & 26.5 & 129.6 & -103.1 \\
6. & 2020 & 57.3 & 62.3 & -5.0 & 26.7 & 143.3 & -116.6 \\
7. & 2021 & 57.5 & 68.9 & -11.4 & 26.9 & 158.5 & -131.6 \\
8. & 2022 & 57.7 & 76.2 & -18.5 & 27.0 & 175.2 & -148.2 \\
9. & 2023 & 57.9 & 84.3 & -26.4 & 27.2 & 193.7 & -166.5 \\
10. & 2024 & 58.0 & 93.3 & -35.3 & 27.4 & 214.2 & -186.8 \\
11. & 2025 & 55.7 & 103.2 & -47.5 & 25.3 & 236.9 & -211.6 \\
12. & 2026 & 55.9 & 114.1 & -58.2 & 25.5 & 261.9 & -236.4 \\
13. & 2027 & 56.1 & 126.3 & -70.2 & 25.6 & 289.7 & -264.1 \\
14. & 2028 & 56.2 & 139.8 & -83.6 & 25.7 & 320.3 & -294.6 \\
15. & 2029 & 56.4 & 154.6 & -98.2 & 25.9 & 354.3 & -328.4 \\
16. & 2030 & 56.6 & 171.1 & -114.5 & 26.1 & 391.7 & -365.6 \\
\hline
\end{tabular}

A few studies were conducted in India to forecast the demand for various food items (Kumar, 1998; Rosegrant et al. 2001; Mittal, 2008 Chand, 2007; Kumar et al. 2009).

The pulse demand projections are derived using estimated growth in population and income. The projection of demand are made for gram and tur which contributes more than 60 per cent of total pulse production. The income (expenditure) elasticities derived from the functional forms for different pulse items are considered to forecast the demand for different pulse items in India. The forecast models based on ARIMA and Three modelling approaches are applied for a wide range of context. For example, time series analysis was applied to forecasting agricultural prices (Jadhav et al. 2017) and comparison of three modeling approaches to simulate regional crop yield (Soltani et al. 2016).

The demand for different pulse items in India up to 2030 are presented in Table 6 . The demand for gram and tur are estimated to reach 62.31 and 143.30 lakh tonnes by the end of 2020 and by the end of 2030 the demand for gram and tur is expected to increase to 171.10 and 391.70 lakh tonnes, respectively. Interestingly the demand for tur is expected to be high as compared to the demand from gram. This is due to the fact that tur is grown in dry lands which have low productivity crop is failure due to lack of moisture availability in soil.

\section{Supply and Demand Gap Analysis for Major Pulses}

Demand and supply projections enable to formulate medium and long-term agricultural policies to achieve self sufficiency in food production. The increase in demand for pulse is mainly due to growth in population and per capita income. On the other hand the supply mainly depends on technological, weather factors and soil productivity.

Out of total pulse production, twenty per cent is assumed to be consumed as feed, seed and industrial purpose. The remaining eighty per cent of production is available for direct human consumption and this quantity is considered as the supply for the present study. The demand-supply projection and their gaps for gram and tur crops up to 2030 are presented in Table 7.

Gram and tur are the staple protein food for vegetarian population which is consumed in larger proportion as compared to other pulses hence they are considered for this study. Presently the supply is more than the demand in the case of gram and this situation continue till 2019. Subsequently, the 
demand for gram would exceed supply to the extent of 47.5 lakh tonnes by 2025 and by the end of 2030 the gap will be to the extent of 114.5 lakh tonnes, leading to increasing the importance of gram.

Tur is another important pulse crops grown extensively in India. Due to low productivity, its consumption demand is very high. The situation of shortage of supply in the country is expected to continue till 2030. The supply-demand gap would be 116.60 lakh tonnes during 2020 and expected to increase up to 365.6 lakh tonnes bythe end of 2030 (Table 7).

\section{CONCLUSION}

The Indian pulses sector is facing two major challenges: Sluggish growth in yields and stagnant acreage which eventually kept production at more or less stagnant levels over a period of six decades. The yield of most of the pulses has shown a miniscule growth over the last six decades. From 1956-57 to 2015-16, the total acreage under pulses has almost been stagnated, however. The annual compound growth rate of gram production recorded three per cent during 2006-07 to 201516 . In the case of tur, accelerated growth rate in area $(1.18 \%)$, production 1.51 but in the case of productivity is just 0.18 per cent during 200607 to 2015-16. The lower productivity of pulses crops is due to lack of sufficient irrigation, below normal monsoon and pulses crops are grown in rain-fed conditions. The short supply of pulses crops led to increase in .demand and prices thereby become out of reach to low level income households, which negatively affect the nutrition and productivity of the human population. To overcome such problems, identify the niche markets, where pulse productivity and area can be increased with cost effective technology and management practices. Continuous dependence on imports is not good for long term. Hence, Central and State Governments together need to address the issues leading to low yield of pulses and undertake actions to promote pulses cultivation.

\section{REFERENCES}

Byerlee, D. and White, R. 1997. Agricultural systems intensification and diversification through food, legumes, technological and policy option. Invited paper presented at III ${ }^{\text {rd }}$ international food, legumes, research conference, Adelaide, Australia, 22-26.
Directorate of pulses development, Pulses in India retrospect and prospects 2016. Government of India Ministry of agriculture.

Chand, Ramesh, 2000. Trade liberalisation, agricultural prices and net social welfare in India. Keynote Paper in Third Asian Conference of Agricultural Economics, 18-20.

Chand, Ramesh, 2007. Demand for foodgrain. Economic and Political weekly (December) 10-13.5. Commodity profile for pulses, 2017.

FAO STAT, 2008, Statistical Data Base 2008.

Farjam, A., Omid, M., Akram, A. and Fazel, Niari, Z. 2014. A Neural Network Based Modeling and Sensitivity Analysis of Energy Inputs for Predicting Seed and Grain Corn Yields J. Agr. Sci. Tech., 16: 767-778.

George, P.S. 1980, The changing pattern of consumer demand for food grains in India. Indian Journal of Agricultural Economics, 35(1):53-68.

Jadhav, V., Chinappa Reddy, B.V. and Gaddi, G.M. 2017. Application of ARIMA Model for Forecasting Agricultural Prices. J. Agr. Sci. Tech., 19: 981-992.

Joshi, P.K. and Saxena, Raka, 2002. A profile of pulses production in India, Facts, trends and opportunities. Indian Journal of Agricultural Economics, 57(3): 326-339.

Joshi, P. K. Asokan, M., Datta, K. K. and Kumar, P., 2000. Socioeconomic constraints to legumes production in rice-wheat cropping systems of India.

Kumar Praduman, P.K. Joshi and Pratap, S. Birthal 2009. Demand projection for food grains in India, Agriculture Economic Research Review, 22(2): 237-243.

Kumar Praduman 1998. Food Demand and Supply Projection for India, Agricultural Economics policy paper -98-01. Indian Agricultural Research Institute, New Delhi.

Mittal, S., 2006. Structural Shift in Demand for Food: Projections for 2020, working paper No.184, ICRIER, New Delhi.

Mittal, Surabhi 2008. Demand and supply trends and projection of food in India, working paper No 209, ICRIEP, New Delhi.

Narayan, P. and Kumar S. 2015. Constraints of growth in area production and productivity of pulses in India: An analytical approach to major pulses. Indian J Agric Res., 49(2):114-124.

Pande, S.P. and Joshi, P.K. 1995. Constraints and Prospects of Legumes in Northern India and the Tarai Region of Nepal. ICRISAT, Patancheru, Hyderabad.

Reddy, A.A. 2004. Consumption pattern, trade and production potential of pulses, Economic and Political Weekly, 39(44): 4854-4860.

Rosegrant, Mark W., Agcaolli-sombilla,M. and Perez, N.D. 1995. Global Food Projections to 2010: implication for investment.2010. discussion paper No.5. International food policy research institute, Washington, D.C.

Safa. M., Samarasinghe, S. and Nejat, M. 2015. Prediction of Wheat Production Using Artificial Neural Networks and Investigating Indirect Factors Affecting It: Case Study in 
Canterbury Province, New Zealand. J. Agr. Sci. Tech., 17: 791-803.

Singh, R.P. 2013. Status paper on Pulses. Government of India, Ministry of Agriculture, Directorate of Pulses Development.

Soltani. A., Bakker M.M., Veldkamp A. and Stoorvogel, J.J. 2016. Comparison of Three Modelling Approaches to Simulate Regional Crop Yield: A Case Study of Winter Wheat Yield in Western Germany. J. Agr. Sci. Tech., 18: 191-206.
Srivastava, S.K., Sivaramane, N. and Mathur, V.C. 2010. Diagnosis of Pulses Performance of India. Agricultural Economics Research Review Vol. 23 January-June 2010, pp. 137-148.

Yildirim, I., Ozsahin, S. and Okan, O.T. 2014. Prediction of Non-Wood Forest Products Trade Using Artificial Neural Networks. J. Agr. Sci. Tech., 16: 1493-1504.

http://vikaspedia.in/agriculture/crop-production/package-ofpractices/pulses/pulses-in-india 
